ARTUR STASZCZYK

DOI : $10.14746 /$ rie.2015.9.15

Uniwersytet Szczeciński

\title{
Stanowisko Parlamentu Europejskiego wobec Partnerstwa Wschodniego
}

\section{Wprowadzenie}

Rozszerzenie UE o kraje środkowoeuropejskie spowodowało przesunięcie jej punktu ciężkości geopolitycznej daleko na Wschód i wymusiło na niej opracowanie nowej koncepcji traktowania obszarów z Unią graniczących. Koncepcja ta w najbardziej skonkretyzowanej postaci została przedstawiona 12 maja 2004 r. w komunikacie Komisji Europejskiej zatytułowanym Strategia Europejskiej Polityki Sqsiedztwa (EPS). Dokument ten za podstawowe cele EPS uznał zapewnienie stabilności, bezpieczeństwa i dobrobytu w sąsiedztwie rozszerzonej UE. Za podstawę relacji UE z sąsiadami Strategia uznawała poszanowanie zasad państwa prawa, reguł dobrego rządzenia, praw człowieka, w tym praw mniejszości, realizację zasad gospodarki rynkowej i zrównoważonego rozwoju (zob. Europejska...). Problemem EPS od samego początku jej funkcjonowania było to, że objęto nią północnoafrykańskie i bliskowschodnie państwa południowośródziemnomorskie, jak i wschodnich sąsiadów UE, co stanowiło zaprzeczenie pierwotnego założenia, że status krajów partnerskich otrzymają wyłącznie Ukraina, Mołdawia i Białoruś. Jednakże wskutek postawy i nacisków wpływowych w UE państw takich jak: Francja oraz Hiszpania ${ }^{1}$ do EPS zostały włączone kraje południowośródziemnomorskie, co w istotny sposób podważyło spójność tej polityki i wzbudziło wiele kontrowersji. Ponadto brak jakichkolwiek, choćby najostrożniejszych stwierdzeń mogących sugerować, że państwa wschodnioeuropejskie zostaną członkami UE pogłębiło wśród nich rozczarowanie tą unijną inicjatywą. Problem ten został dostrzeżony przez niektóre państwa UE, które zaproponowały wzmocnienie oferty europejskiej na kierunku wschodnim poprzez powołanie Partnerstwa Wschodniego (PW) UE. W dokumencie zatytułowanym Propozycja Polsko-Szwedzka. Partnerstwo Wschodnie założono, że celem projektu jest pogłębiona współpraca ze wschodnimi sąsiadami - sześcioma krajami partnerskimi objętymi EPS (znoszenie restrykcji wizowych, stworzenie strefy wolnego handlu, harmonizacja systemów prawnych, społecznych, ekonomicznych i politycznych krajów partnerskich z UE) oraz

1 Kraje te w swojej polityce zagranicznej szczególne miejsce poświęcająpaństwom poludniowego wybrzeża Morza Śródziemnego, które ich zdaniem powinny być traktowane priorytetowo. Postrzegają one EPS jako instrument wzmocnienia wspólpracy śródziemnomorskiej, wykazując dużo mniejsze zainteresowanie polityką UE wobec Bialorusi, Ukrainy i Moldawii, a Federację Rosyjską traktując jako partnera strategicznego (zob. szerzej: Kołakowska, 2004; Wojna, 2004). 
zastapienie dotychczasowych umów o partnerstwie i współpracy nowymi układami (zob. Propozycja...).

$\mathrm{Na}$ początku grudnia 2008 r. Komisja Europejska (KE) zaakceptowała polsko-szwedzką koncepcję PW. Propozycja KE zakładała między innymi: 1) zawarcie nowych układów o stowarzyszeniu, obejmujących porozumienia o wolnym handlu; 2) stworzenie przez UE kompleksowych programów finansowych zmierzających do poprawy zdolności administracyjnych partnerów; 3) stopniową integrację z gospodarką UE i harmonizację przepisów prawa; 4) dążenie do zniesienia obowiązku wizowego dla obywateli krajów partnerskich; 5) dalsze otwieranie unijnego rynku pracy; 6) poprawę bezpieczeństwa energetycznego UE i jej wschodnich partnerów; 7) ustanowienie programów na rzecz rozwoju społeczno-gospodarczego w krajach partnerskich; 8) utworzenie czterech wielostronnych platform politycznych w dziedzinach: demokracji, dobrych rządów i stabilności, integracji gospodarczej i konwergencji z polityką UE, bezpieczeństwa energetycznego, kontaktów międzyludzkich; 9) nasilenie bezpośrednich kontaktów oraz zwiększenie zaangażowania społeczeństwa obywatelskiego i wzrost znaczenia Parlamentu Europejskiego we wzajemnych relacjach; 10) przeznaczenie dodatkowych $350 \mathrm{mln}$ euro w latach 2010-2013 na wsparcie projektu oraz przesunięcie na jego realizację $250 \mathrm{mln}$ euro ze środków na regionalne programy w ramach EPS (zob. Partnerstwo...). Przyśpieszeniu realizacji projektu PW niewatpliwie pomogła rosyjska interwencja w Gruzji latem 2008 r., która uświadomiła zwłaszcza przywódcom państw tzw. starej Unii jak ważne dla bezpieczeństwa europejskiego jest wciaganie państw postradzieckich w orbitę wpływów Zachodu poprzez np. ustanowienie $z$ nimi stref wolnego handlu, co oznaczałoby przyjęcie przez te państwa ponad $60 \%$ norm prawa wspólnotowego. Pozwoliłoby to tym państwom wejść ,tylnymi" drzwiami do unijnego przedsionka i uzyskać status zbliżony do tego jakie w relacjach z UE maja Norwegia czy Szwajcaria (Pawlicki, 2008). Ostatecznie inauguracja PW miała miejsce w maju 2009 r. w Pradze, gdzie przywódcy i przedstawiciele państw UE oraz Armenii, Azerbejdżanu, Gruzji, Białorusi, Mołdawii i Ukrainy przyjęli wspólną deklarację, dając tym samym początek nowego otwarcia UE w dziedzinie jej polityki wschodniej (zob. Wspólna...).

Celem artykułu jest analiza stanowiska Parlamentu Europejskiego (PE) wobec powstania i rozwoju PW oraz ukazanie procesu kształtowania się wymiaru parlamentarnego partnerstwa, będącego konsekwencją wzrostu roli i znaczenia PE w kreowaniu unijnej polityki wschodniej. Należy podkreślić, że PE jest jedyną mającą demokratyczną legitymację instytucją unijną reprezentującą społeczeństwa Europy. Oznacza to, że PE w swojej działalności może powoływać się na wolę europejskiej opinii publicznej, zarazem ją kształtując dzięki posiadaniu szerokiego spektrum instrumentów oddziaływania (debaty parlamentarne, rezolucje, raporty, zalecenia). Pozwala mu to wpływać poza zakresem swoich traktatowych kompetencji na decyzje Rady UE będącej głównym organem kształtującym politykę UE wobec wschodnich sąsiadów. Dlatego zamierzeniem autora nie jest analiza kompetencji decyzyjnych PE w obszarze polityki wschodniej UE (rola w procesie zawierania umów stowarzyszeniowych, uprawnienia legislacyjne, budżetowe, kontrolne), ale weryfikacja hipotezy zakładającej, że PE jest kluczową instytucją wpływu politycznego w procesie kształtowania unijnej polityki wobec wschodnioeuropejskich państw partnerskich. 


\section{Rezolucje jako instrument wyrażania stanowiska PE wobec unijnej polityki wschodniej}

Podstawowym instrumentem wpływu PE na proces kształtowania się PW są przyjmowane na jego forum rezolucje. Są to najliczniejsze dokumenty posiedzeń PE, które dzielą się na legislacyjne (dotyczące projektów legislacyjnych) oraz nielegislacyjne - wszystkie pozostałe (Ogonowska, 2006, s. 18). Parlament próbuje wpływać na kształt i kierunki rozwoju polityki wschodniej UE przede wszystkim poprzez przyjmowanie rezolucji nielegislacyjnych, które choć pozbawione mocy prawnie wiążącej pozwalają temu organowi wyrazić swoje stanowisko w stosunku do podstawowych kwestii będących przedmiotem tej polityki. W rezolucjach tych PE podkreśla swoje kluczowe znaczenie dla pogłębiania debaty politycznej w ramach UE co do kształtu PW oraz rolę w utrwalaniu wolności i demokracji wśród sąsiadujących krajów partnerskich. Oznacza to, że w przypadku krajów objętych inicjatywą Partnerstwa Wschodniego, PE definiuje swoją rolę jako strażnika wartości i zasad obejmujących demokrację, praworządność, poszanowanie praw człowieka i podstawowych wolności, gospodarkę rynkową, zrównoważony rozwój, dobre rządy, niezawisłość sądownictwa, zwalczanie korupcji, utrzymanie wolności mediów i promowanie organizacji pozarządowych. Wartości te i zasady powinny być podstawowym miernikiem oceny wschodnich krajów partnerskich w ich relacjach z UE. Stanowisko to wynika z przyjętego przez PE założenia, że inicjatywa PW stanowi polityczne ramy rozwoju wschodniego wymiaru EPS, którego celem jest pogłębianie i zacieśnianie stosunków pomiędzy UE a jej wschodnimi sąsiadami, promowanie politycznego stowarzyszenia, integracji gospodarczej i zbliżania ustawodawstw, przy jednoczesnym wspieraniu reform politycznych, społecznych i gospodarczych w krajach partnerskich. Dlatego PE proces zbliżenia państw wschodnioeuropejskich do UE i nadanie im perspektywy europejskiej uzależnia od przeprowadzania wolnych wyborów zgodnych z normami i zobowiązaniami międzynarodowymi, walki z korupcją, zwłaszcza w sądownictwie i policji, swobodnego funkcjonowania organizacji społeczeństwa obywatelskiego. Podkreśla, że przeszkodą w procesie zbliżenia z UE są utrzymujące się w wielu krajach partnerskich poważne problemy związane $\mathrm{z}$ poszanowaniem wolności wypowiedzi, zwłaszcza w mediach, wolności zrzeszania się i wolności zgromadzeń. PE zwraca również uwage na znaczenie związków zawodowych i dialogu społecznego jako części rozwoju demokratycznego partnerów wschodnich i sprzeciwia się ograniczaniu praw związkowych i pracowniczych w tych państwach. Podkreślając swoją rolę w utrwalaniu wolności i demokracji wśród sąsiadujących krajów partnerskich PE opowiada się za wykorzystywaniem takich instrumentów jak liberalizacja reżimu wizowego (docelowo jego zniesienie) czy integracja gospodarcza w ramach pogłębionej strefy wolnego handlu do promowania wartości demokratycznych w tych państwach. W celu inkorporacji wartości europejskich na grunt wschodnich państw partnerskich należy zdaniem PE zwiększyć środki na programy stypendialne służące mobilności studentów, naukowców i przedsiębiorców pochodzących z tych państw (zob. Rezolucja Parlamentu Europejskiego $z$ dnia 7 kwietnia 2011 r...., s. 105). Wedhug opinii PE istotnym elementem demokratyzcji państw PW jest również budowa niezależnych organizacji społeczeństwa obywatelskiego. Postulatem PE jest zwiększenie przez UE finansowania rozwoju 
społeczeństwa obywatelskiego w krajach wschodnioeuropejskich oraz ustanowienie patnerstw między podmiotami demokratycznymi w UE, a ich odpowiednikami na Wschodzie (zob. Rezolucja Parlamentu Europejskiego z dnia 14 grudnia 2011 r...., s. 26). Również najważniejszy instrument realizacji PW, jakim są układy stowarzyszeniowe, nie stanowią w opinii PE celu samego w sobie, lecz mają przede wszystkim propagować reformy służące zbliżeniu wschodnich krajów partnerskich z UE i inkorporacji przez nie unijnych wartości i zasad. Z tym stanowiskiem wiąże się postulat PE, aby UE opracowała długofalową strategię propagowania wartości europejskich wśród społeczeństw krajów PW. Istotą polityki UE wobec wschodnioeuropejskich państw partnerskich winno więc być zdaniem PE wzmocnienie stosowania zasady „więcej za więcej" i realizowanie przez UE podejścia dwutorowego polegającego na kierowaniu wysokich wymagań pod adresem rząów krajów PW przy jednoczesnym zachowaniu otwartej i zaangażowanej postawy wobec społeczeństw tych państw, która zachęciłaby je do opowiedzenia się za wartościami, na których opiera się UE. Aby ta polityka mogła być skutecznie realizowana konieczne jest finansowanie PW na odpowiednim poziomie wyższym niż ten proponowany przez KE i włączenie PE w proces przyznawania lub wycofywania środków budżetowych w związku ze stosowaniem zasady ,więcej za więcej” lub „mniej za mniej”. Z tymi zaleceniami PE współgra postulat decentralizacji PW poprzez ustanowienie intensywnego dialogu z podmiotami po obydwu stronach i przekazanie im odpowiedzialności za realizację partnerstwa. W kontekście podpisywania przez UE i państwa partnerskie układów stowarzyszeniowych, PE jednoznacznie potępia naciski ze strony Rosji na kraje PW. W swoim stanowisku PE uważa te naciski za niedopuszczalne i wzywa Rosję do powstrzymania się od działań będących wyraźnym naruszeniem zasad zawartych w Akcie Końcowym KBWE. Zdecydowanie podkreśla, że swoboda decydowania państw PW w kształtowaniu swojej polityki zagranicznej nie powinna pociagać za sobą działań Rosji, która poprzez wykorzystywanie będących w jej dyspozycji instrumentów wpływu w dziedzinie handlu, polityki wizowej, ograniczonej mobilności pracowników, ingerencji w zamrożone konflikty próbuje destabilizować sytuację wewnętrzną w tych krajach. Nie godząc się na takie postępowanie Rosji zmierzające do zniechęcenia krajów PW do politycznego i gospodarczego stowarzyszenia z UE, PE wzywa KE i Europejską Służbę Działań Zewnętrznych (ESDZ) do potraktowania tych działań jako godnych ubolewania oraz do podjęcia kroków uniemożliwiających Moskwie takie postępowanie. Ponadto jest zdania, że postępująca integracja krajów partnerskich z UE nie stoi w sprzeczności z interesami Rosji i nie może być przez nią postrzegana jako gra o sumie zerowej. Istotnym problemem w relacjach UE - wschodnioeuropejskie państwa partnerskie zauważalnym przez PE jest natężenie sporów i konfliktów terytorialnych w Gruzji, Azerbejdżanie, Armenii i Mołdawii, które stanowią istotną przeszkodę w procesie dalszej ich integracji z UE. W tej kwestii dla PE kluczowe jest powstrzymywanie się państw partnerskich od używania siły lub gróźb jej użycia przy rozstrzyganiu sporów w regionie i ich rozwiązywanie poprzez negocjacje w formie uznanej na szczeblu międzynarodowym i opartej na zasadach określonych w prawie międzynarodowym. W relacjach UE z krajami partnerskimi istotne miejsce zajmuje współpraca energetyczna, która jest jednym z priorytetów PW. Instrumentem realizacji tej współpracy jest Traktat o Wspólnocie Energetycznej, który kładzie podwaliny pod zintegrowany regionalny rynek energii. Dla PE prioryte- 
tem jest przystąpienie do Wspólnoty Energetycznej wszystkich państw PW. Ponadto PE wzywa do zawierania klauzul dotyczących bezpieczeństwa energetycznego we wszystkich umowach z krajami PW w celu zagwarantowania pełnego przestrzegania przepisów obowiązujących w obrębie wewnętrznego rynku energii UE oraz do uwzględniania w tych umowach mechanizmu wczesnego ostrzegania w sprawach energii, którego zadaniem będzie ocena potencjalnych zagrożeń i problemów związanych z przesyłem i dostawami energii z państw trzecich. Klauzule bezpieczeństwa energetycznego mają także służyć ustanowieniu wspólnych ram udzielania wzajemnej pomocy w duchu solidarności i określać sposoby rozstrzygania sporów. Podsumowując stanowisko PE wobec wymiaru wschodniego EPS należy podkreślić, że organ ten traktuje przyjmowane przez siebie rezolucje jako integralny element polityki UE wobec państw partnerskich. W dokumentach tych domaga się zwiększenia swoich uprawnień budżetowych w dziedzinie realizacji PW, ubolewa nad faktem, że nie zawsze zasięga się jego opinii podczas sporządzania planów działania ani nie informuje się go o postępach w procesie wdrażania reform w krajach partnerskich, a także apeluje o przyznanie posłom do PE statusu obserwatorów z prawem uczestnictwa w posiedzeniach podkomisji zajmujących się kwestiami politycznymi i prawami człowieka (zob. Rezolucja Parlamentu Europejskiego z dnia 23 października 2013 r....).

\section{Euronest jako instrument realizacji polityki wschodniej PE}

Koncepcja ustanowienia Zgromadzenia Parlamentarnego Partnerstwa Wschodniego (Euronest) pojawiła się już w rezolucji PE z dnia 15 listopada 2007 roku. Akt ustanawiajacy Euronest został podpisany w Brukseli w dniu 3 maja 2011 r. przez posłów reprezentujących $\mathrm{PE}$ oraz parlamenty wschodnioeuropejskich państw partnerskich. Oznaczało to nadanie PW wymiaru parlamentarnego, którego najważniejszymi obszarami (platformami) tematycznymi są: 1) sprawy dotyczące podstawowych wartości takich jak demokracja, rządy prawa, poszanowanie praw człowieka i podstawowych wolności, a także zasad gospodarki rynkowej, zrównoważonego rozwoju i dobrego sprawowania rządów; 2) integracja gospodarcza państw partnerskich z UE, wspieranie w tych krajach reform społeczno-gospodarczych, ujednolicenie prawa i norm tych krajów z prawami i normami UE, stworzenie stref wolnego handlu; 3) współpraca energetyczna pomiędzy UE a wschodnioeuropejskimi państwami partnerskimi; 4) promowanie wzajemnych kontaktów międzyludzkich, współpracy kulturalnej i dialogu międzykulturowego, współpracy w dziedzinie nauki i szkolnictwa. Do zadań Euronest należą: 1) stanowienie forum debaty parlamentarnej, kontroli i monitorowania wszelkich spraw dotyczących PW; 2) przyjmowanie rezolucji, zaleceń i opinii, których adresatami są szczyty PW, instytucje, organy, grupy i konferencje ministerialne powiązane Z rozwojem PW; 3) zapewnienie wymiany informacji, szkoleń i programów edukacyjnych służących optymalizacji prac parlamentarnych i absorpcji unijnych wzorców na grunt parlamentów państw partnerskich; 4) udzielanie pomocy w procesie harmonizacji ustawodawstwa krajowego wschodnioeuropejskich państw partnerskich z prawodawstwem unijnym. Strukturę Euronest tworzą: Zgromadzenie Plenarne, Prezydium, komisje i sekretariat (zob. Akt..., s. 1-5). Zgromadzenie Parlamentarne Euronest jest 
ciałem złożonym z 60 posłów do PE oraz 10 posłów z każdego z reprezentowanych parlamentów wschodnioeuropejskich państw partnerskich. Zbiera się ono na posiedzeniach plenarnych zwoływanych $\mathrm{z}$ reguły raz $\mathrm{w}$ roku. Jego organizacja opiera się na delegacjach parlamentarnych wyznaczonych przez obie części składowe. Wybierają one ze swojego grona Prezydium złożone $z$ dwóch równych rangą wspólprzewodniczących (po jednym z każdej części składowej Zgromadzenia) i określonej liczby wiceprzewodniczących (po jednym z każdego wschodnioeuropejskiego państwa partnerskiego $\mathrm{z}$ wyjątkiem państwa, które reprezentuje jeden ze współprzewodniczących i takiej samej liczby z PE), które zbiera się przynajmniej dwa razy do roku. Do jego kompetencji należy określanie składu i zadań komisji, sporządzanie projektu porządku obrad Zgromadzenia, ustalanie procedur jego funkcjonowania, udzielanie zgody na sprawozdania, projekty rezolucji i zalecenia składane przez komisje. Istotną rolę w strukturze Euronest odgrywają również stałe komisje parlamentarne takie jak: 1) Komisja Spraw Politycznych, Praw Człowieka i Demokracji (właściwa w sprawach rozwoju demokracji, propagowania dialogu politycznego, w tym również ze stronami trzecimi, pokojowego rozwiązywania konfliktów, utrzymania pokoju, bezpieczeństwa, przestrzegania standardów wyborczych, zwalczania korupcji); 2) Komisja ds. Integracji Gospodarczej i Konwergencji z Polityką UE (właściwa w sprawach stosunków gospodarczych, finansowych i handlowych między UE i krajami partnerskimi a stronami trzecimi, sprawach dotyczących finansowania PW, zrównoważonego rozwoju, zarządzania środowiskiem naturalnym, problemu migracji); 3) Komisja ds. Bezpieczeństwa Energetycznego (właściwa w sprawach powstania zróżnicowanego rynku energii, monitorowania mechanizmów wzajemnego wsparcia, harmonizacji polityki energetycznej i ustawodawstwa, dywersyfikacji tras dostawczych i tranzytowych); 4) Komisja Spraw Społecznych, Edukacji, Kultury i Społeczeństwa Obywatelskiego (właściwa w sprawach równości płci, współpracy w dziedzinie kultury i edukacji, sprawach dotyczących młodzieży, stosunków z organizacjami pozarządowymi, monitorowania rozwoju społeczeństwa informacyjnego i roli mediów). Każda z komisji wybiera ze swojego grona Prezydium złożone $\mathrm{z}$ dwóch równych rangą współprzewodniczących i czterech współwiceprzewodniczących. Do głównych zadań komisji należy opracowywanie sprawozdań w sprawach właściwych dla ich kompetencji, które następnie przedstawiane sa Zgromadzeniu Parlamentarnemu Euronest (zob. Regulamin..., s. 2-19).

Zgromadzenie Parlamentarne Euronest jako instytucja odpowiedzialna za parlamentarne doradztwo, kontrolę i monitorowanie PW odgrywa istotną rolę w rozwoju tej unijnej inicjatywy. Nadrzędnym celem Euronest jest przyspieszenie politycznego stowarzyszenia i pogłębienie integracji gospodarczej między UE a wschodnioeuropejskimi państwami partnerskimi. Organ ten wychodzi z założenia, że integracja gospodarek państw PW z gospodarkami UE będzie determinować ich integrację polityczną ze strukturami europejskimi. Dlatego Euronest w przyjmowanych przez siebie stanowiskach podkreśla, że pogłębiona i kompleksowa strefa wolnego handlu (DCFTA) musi stanowić część układu o stowarzyszeniu, zawierającego również klauzule odnoszące się do dialogu politycznego w kwestiach praw człowieka, przestrzegania zasad demokracji i rządów prawa. Ponadto negocjacje w sprawie DCFTA zdaniem Euronest muszą łączyć się z programem reform gospodarczych realizowanych w państwach $\mathrm{PW}$. Celem 
tych reform musi być spełnienie określonych przez KE wymogów dotyczących układów stowarzyszeniowych. Euronest podkreśla, że przyjęcie DCFTA będzie dla krajów PW impulsem do wielkiej przebudowy podstaw funkcjonowania państw i społeczeństw PW oraz ich kultury prawnej i gospodarczej. Ponadto wzywa UE do zwiększenia pomocy finansowej i technicznej w reformowaniu gospodarek państw wschodnioeuropejskich w celu dostosowania ich do standardów unijnych, krytykując równocześnie brak wystarczających funduszy przeznaczanych na realizację wymiaru wschodniego EPS. Analizując treść stanowiska zgromadzenia parlamentarnego Euronest wobec zawarcia przez UE i państwa wschodnioeuropejskie DCFTA należy podkreślić, że instytucja ta opowiada się za przyjęciem przez UE całościowej wizji integracji gospodarek państw PW ze wspólnym rynkiem, która obejmowałaby nie tylko zagadnienia związane $\mathrm{z}$ wolnym handlem, ale również z ochroną środowiska i zrównoważonym rozwojem (zob. Rezolucja Zgromadzenia Parlamentarnego Euronest $z$ dnia 3 kwietnia 2012 r...., s. 5-8). Istotnym elementem realizacji tej wizji winno być zbliżenie ustawodawstw krajów PW w zakresie gospodarczym do ustawodawstwa UE. Zbliżenie to należy zgodnie ze stanowiskiem Euronest rozumieć, nie tylko jako harmonizację przepisów prawnych, ale przede wszystkim jako transformację struktur administracyjnych, sądowniczych i społecznych, które byłyby w stanie w sposób skuteczny implementować przepisy unijne na grunt krajowy. Dlatego dla państw wschodnioeuropejskich kluczowymi kwestiami w procesie harmonizacji prawa powinny być reforma systemu sądownictwa, walka z korupcją, ustanowienie mechanizmów koordynacji i monitorowania procesu zbliżania ustawodawstw oraz organów odpowiedzialnych za egzekwowanie prawa (zob. Rezolucja Zgromadzenia Parlamentarnego Euronest z dnia 28 maja 2013 r...., s. 10-14). W ramy preferowanej przez Euronest integracji gospodarczej wpisuje się również współpraca między wschodnioeuropejskimi państwami partnerskimi a UE w dziedzinie bezpieczeństwa energetycznego. Jego zwiększenie jest jednym z najważniejszych celów PW i dlatego kwestia ta stanowi przedmiot szczególnego zainteresowania zgromadzenia parlamentarnego Euronest, które dostrzega, że znaczna zależność państw importujących surowce energetyczne od ich dostawców z dominującą pozycją na rynku może być wykorzystywana jako instrument wywierania nacisku na politykę zagraniczną importerów. Dlatego dywersyfikacja dostawców i dróg przesyłowych jest zdaniem Euronest konieczna po to, aby umocnić geopolityczną niezależność państw PW. W tym celu należy stworzyć zintegrowany rynek energii między UE a partnerami wschodnioeuropejskimi w oparciu o Traktat o Wspólnocie Energetycznej. Euronest podkreśla szczególną rolę regionu Morza Czarnego w odniesieniu do dywersyfikacji źródeł i dróg dostaw surowców energetycznych i dlatego opowiada się za określeniem przez wszystkie podmioty PW wspólnych priorytetów w tej dziedzinie. Do priorytetów tych powinna należeć rozbudowa transkaspijskiego korytarza naftowego i gazowego oraz południowego korytarza gazowego wraz z dalszą rozbudową rurociagu Baku-Tbilisi-Ceyhan oraz Baku-Supsa, co umożliwiłoby połączenie państw środkowoazjatyckich z Europą zarówno w wymiarze gospodarczym, jak i politycznym oraz dałoby krajom partnerskim z Europy Wschodniej możliwość pozyskania wiarygodnych partnerów transportowych (zob. Rezolucja Zgromadzenia Parlamentarnego Euronest z dnia 28 maja 2013 r...., s. 15-23). Bezpieczeństwo energetyczne jest istotnym komponentem środowiska bezpieczeństwa regionalnego, którego budowa należy 
do priorytetów PW. Dlatego tworzenie wspólnej przestrzeni stabilności i pokoju stanowi również przedmiot zainteresowania Euronest. Najważniejszą przeszkodą w powstaniu strefy stabilności i bezpieczeństwa w sąsiedztwie UE są nierozwiązane konflikty występujące na obszarze wschodnioeuropejskich państw partnerskich. Do istniejących od dawna konfliktów dołączył w ostatnim czasie najpoważniejszy z nich wszystkich konflikt zbrojny na Ukrainie mający wpływ na całą architekturę bezpieczeństwa europejskiego. Stał się on przedmiotem szczególnego zainteresowania UE, w tym również Euronestu. W przyjętej w marcu 2015 r. rezolucji, Euronest wyraźnie określił Rosję jako militarnego agresora na Ukrainie i zdecydowanie potępił aneksję Krymu, którą uznał za sprzeczną z podstawowymi zasadami prawa międzynarodowego (zob. Resolution on the Russian ..., s. 2). Oprócz kwestii związanych z integracją gospodarczą i bezpieczeństwem regionalnym, istotną rolę w pracach Euronest odgrywa problematyka inkorporacji do systemów politycznych wschodnioeuropejskich państw partnerskich zasad demokracji, rządów prawa, poszanowania praw człowieka oraz podstawowych wolności. Euronest wzywa do pogłębienia dialogu politycznego między podmiotami PW w kwestii budowania demokracji i realizacji reform demokratycznych, w szczególności poprzez wymianę poglądów z przedstawicielami rządów i parlamentów państw partnerskich, partii politycznych, organizacji pozarządowych i mediów. Zachęca partnerów z Europy Wschodniej do szybszej transformacji własnych systemów politycznych w kierunku demokracji, wzywa ich do dopilnowania, aby wybory parlamentarne jak i prezydenckie były wolne, uczciwe, przejrzyste i przeprowadzone zgodnie z normami OBWE. Euronest podkreśla również rolę konsultacji społecznych w trakcie realizacji programu reform oraz znaczenie otwartej debaty publicznej, zwłaszcza z udziałem przedstawicieli młodzieży i kobiet dla przejrzystości procesu decyzyjnego. W ramach pogłębiania wzajemnych relacji, Euronest wzywa do nawiązywania partnerstwa między podmiotami z UE takimi jak: partie polityczne, związki zawodowe, organizacje pozarządowe, związki religijne, media, organy samorządu terytorialnego i zawodowego, uniwersytety, organizacje młodzieżowe i kulturalne, a ich odpowiednikami w krajach partnerskich w Europie Wschodniej. Euronest podkreśla ponadto szczególną rolę niezależnych i wolnych mediów dla funkcjonowania demokracji w państwach wschodnioeuropejskich. Dlatego w przyjętym przez siebie stanowisku instytucja ta wzywa partnerów z Europy Wschodniej do zapewnienia swoim obywatelom prawa do informacji, domaga się poszanowania zasady niezależności mediów, ich pluralizmu oraz sprzeciwia się monopolizacji mediów i ingerencji w ich działalność. Ponadto Euronest zwraca uwagę na fakt, że wielu dziennikarzy we wschodnioeuropejskich państwach partnerskich jest obiektem zastraszania i prześladowania lub stało się ofiarą agresji i ataków z powodu swojej działalności. Podkreśla, że władze tych państw nie mogą tolerować takich praktyk i muszą one działać w kierunku postawienia osób odpowiedzialnych za te czyny przed sądem (zob. Rezolucja Zgromadzenia Parlamentarnego Euronest $z$ dnia 3 kwietnia 2012 r...., s. 9-15). W opinii Euronest umacnianie demokracji i praworządności we wschodnioeuropejskich państwach partnerskich nie będzie możliwe bez budowy niezależnego społeczeństwa obywatelskiego. Aby mogło ono funkcjonować konieczne jest zagwarantowanie w tych państwach wolności zrzeszania się i zgromadzeń, wolności wypowiedzi, swobody działania prasy i mediów oraz dostępności internetu. Dlatego wszystkie organizacje pozarządowe, z wyjątkiem 
tych, które podżegają do dyskryminacji rasowej, etnicznej, religijnej lub innej, powinny mieć możliwość rejestracji i zapewnione prawo do swobodnego działania, bez ingerencji ze strony rządu. Zdaniem Euronest szczególną rolę organizacje społeczeństwa obywatelskiego powinny odgrywać w prowadzeniu dialogu dotyczącego praw człowieka, w tym praw mniejszości, w monitorowaniu procesu wyborczego i dbaniu o to, aby przebiegał on zgodnie $\mathrm{z}$ normami międzynarodowymi. Euronest apeluje ponadto do władz państw PW, aby zwalczaly wszelkie przejawy przemocy wobec kobiet, traktując je jako przestępstwa i naruszenia praw człowieka oraz dążyły do pełnego równouprawnienia płci we wszystkich wymiarach jak i wspierały mechanizmy międzykulturowego dialogu a także politykę zwiększania zatrudnienia i integracji społecznej wśród młodzieży. Istotną rolę w budowie społeczeństwa obywatelskiego powinna odgrywać również współpraca w dziedzinie kultury, edukacji, szkoleń, badań naukowych, która wspierałaby rozwój kontaktów międzyludzkich, przyczyniając się zarazem do intensyfikacji dialogu międzykulturowego (zob. Rezolucja Zgromadzenia Parlamentarnego Euronest $z$ dnia 3 kwietnia 2012 r....).

Analizując treść przyjmowanych przez Euronest rezolucji należy podkreślić, że stanowią one instrument wywierania wpływu na rządy wschodnioeuropejskich państw partnerskich, którego celem jest inkorporacja przez nie standardów europejskich w dziedzinach demokracji, praw człowieka, społeczeństwa obywatelskiego, rządów prawa oraz gospodarki. Treść tych dokumentów jest uwzględniana przez PE w uchwalanych na jego forum rezolucjach odnoszących się do stosunków UE z obszarami sąsiedzkimi. Rezolucje te powielają często zapisy przyjęte wcześniej przez Euronest, co sprawia, że problematyka wschodnioeuropejskiego obszaru sąsiedzkiego jest stale obecna na szczeblu instytucji unijnych. Jednakże treść przyjmowanych przez Euronest rezolucji jest często nieostra i pełna ogólnikowych sformułowań. Wynika to z konieczności zawierania szeregu kompromisów, które warunkują uzyskanie zgody ze strony parlamentarzystów reprezentujących kraje wschodnioeuropejskie na przyjęcie rezolucji. Jest to pochodną rozwiązań przyjętych w Regulaminie Zgromadzenia Parlamentarnego Euronest, które zakładają, że decyzje podejmowane są większością dwóch trzecich głosów obecnych posłów, a także dopuszczają możliwość odrębnego głosowania tą samą większością w każdej z dwóch składowych Zgromadzenia (zob. Regulamin..., s. 10). Ponadto czynnikiem utrudniającym efektywne działanie Euronest jest niski poziom kultury demokratycznej we wschodnioeuropejskich krajach partnerskich i wzrost $w$ nich tendencji autorytarnych. Procesowi temu towarzyszy niechęć do współpracy regionalnej, która determinowana jest nierozstrzygniętymi konfliktami terytorialnymi. Oznacza to, że rezultaty dialogu międzyparlamentarnego prowadzonego na forum Euronest są niezadowalające w dziedzinie absorpcji przez wschodnioeuropejskie kraje partnerskie zasad i wartości UE.

\section{Podsumowanie}

Ze stanowiska PE wobec rozwoju Partnerstwa Wschodniego, wynika, że organ ten określający siebie „strażnikiem demokracji” szczególną wagę przywiązuje do inkorporacji przez wschodnioeuropejskie kraje partnerskie wartości demokratycznych. Ucz- 
ciwość procesu wyborczego i przestrzeganie standardów demokratycznych jest dla PE warunkiem pogłębiania współpracy ze wschodnimi krajami partnerskimi. Z racji posiadania kompetencji w dziedzinie zatwierdzania umów stowarzyszeniowych, będących najszerszą formułą współpracy UE z państwami partnerskimi, stanowiska PE, które przyjmują najczęściej formę rezolucji nielegislacyjnych mają istotną rangę polityczną. Ich przyjmowanie czyni z PE instytucję wpływu politycznego, co sprawia, że wartości takie jak: demokracja, prawa człowieka, rządy prawa są uwzględniane w unijnych, jak i krajowych strategiach oraz decyzjach określających charakter polityki zagranicznej całej Unii, jak i jej poszczególnych członków, a klauzule odnoszące się do tych wartości są dołączane do zawieranych przez UE umów stowarzyszeniowych. To działalność PE na kierunku wschodnim unijnej polityki zagranicznej powoduje, że UE uzależnia pogłębianie współpracy $\mathrm{z}$ danym państwem partnerskim od postępów we wdrażaniu rozwiązań demokratyzujących jego system społeczno-polityczny. Ponadto dialog międzyparlamentarny prowadzony na forum Euronest mimo szeregu barier ograniczających jego efektywność stanowi jednak jeden z instrumentów europeizacji kultury politycznej wschodnioeuropejskich państw partnerskich. Należy podkreślić, że PE jest spośród organów UE największym orędownikiem zbliżenia pomiędzy UE a państwami sąsiedzkimi i nadania ich stowarzyszeniu z UE procesu podobnego do procesu akcesyjnego. Współpraca z państwami partnerskimi powinna zdaniem PE obejmować następujące cele: zacieśnienie partnerstwa strategicznego, czyli wzmocnienie integracji partnerów wschodnich w wymiarze politycznym, gospodarczym i kulturalnym w oparciu o wzajemne wartości, interesy i zobowiązania do przestrzegania prawa międzynarodowego, wzmocnienie kontaktów międzyludzkich między UE a krajami PW, utworzenie sieci powiązań społecznych oraz wspieranie modernizacji i orientacji proeuropejskiej (zob. Rezolucja Parlamentu Europejskiego z dnia 12 marca 2014 r....). Jednakże cele te wyznaczone przez PE nie są obecnie łatwe do spełnienia, gdyż we wschodnioeuropejskich państwach partnerskich silne są obecnie tendencje autorytarne i następuje regres w odniesieniu do przestrzegania podstawowych zasad demokracji. Ponadto elity polityczne tych krajów przedkładają stabilizację wewnętrzną ponad transformację ustrojową, co związane jest ze szczególną pozycją oligarchów w systemie politycznym i ekonomicznym oraz występowaniem korupcji na wielką skalę. Sytuacja ta w połączeniu z niewystarczającymi środkami finansowymi przeznaczanymi przez UE na realizację $\mathrm{PW}$ powoduje, że UE ma utrudnione zadanie w promowaniu swoich interesów i wartości w regionie (Marcinkowska, 2013, s. 25). Dlatego działania PE w dziedzinie budowy parlamentarnego wymiaru PW również napotykają na szereg przeciwności związanych z dysfunkcjonalnością systemów politycznych i społeczno-ekonomicznych państw UE i wschodnich krajów partnerskich, co obniża ich efektywność.

\section{Bibliografia}

Akt Ustanawiajacy Zgromadzenie Parlamentarne Euronest, Bruksela, 3 maja 2011 r., www.europarl.europa.eu/meetdocs/2009_2014/documents/nest/dv/865/865531/865531_1_pl.pdf, 14.05.2015.

Wojna B. (2004), Stanowisko Hiszpanii wobec europejskiej polityki sasiedztwa, http://www.pism.pl/ biuletyn_content/id/102, 25.10.2013. 
Europejska Polityka Sasiedztwa - Strategia - Komunikat Komisji, Bruksela, 12 maja 2004 r., COM (2004) 373, archiwum - ukie.plskawue.gov.pl, 25.06.2013.

Kołakowska A. (2004), Stanowisko Francji wobec europejskiej polityki sasiedztwa, http://www.pism.pl/ biuletyn_content/id/104, 25.10.2013.

Marcinkowska P. (2013), Przeglad Europejskiej Polityki Sasiedztwa $w$ dobie zmian politycznych w sqsiedztwie UE po 2010 r., „Studia Europejskie”, nr 1.

Ogonowska A. (2006), Dokumenty i publikacje instytucji i organów Unii Europejskiej, „Zeszyty OIDE", nr 6.

Partnerstwo wschodnie - UE otwiera nowy, ambitny rozdzial w stosunkach z sqsiadami ze Wschodu, Bruksela, 3 grudnia 2008 r., http://europa.eu/rapid/pressReleasesAction.do?reference $=I P / 08 /$ $1858 \&$ format $=$ HTML, 27.08.2009.

Pawlicki J. (2008), Partnerstwo Wschodnie modne w Brukseli, http://wyborcza.pl/ 1,86117,5842906,Partnerstwo Wschodnie modne w Brukseli.html, 24.10.2008.

Propozycja Polsko-Szwedzka. Partnerstwo Wschodnie, Warszawa 2008, http://www.msz.gov.pl/Propozycja,Polsko-Szwedzka,19890.html, 25.04.2009.

Regulamin Zgromadzenia Parlamentarnego Euronest, Dz. U. C 198 z 6.07.2011.

Resolution on the Russian military aggression against Ukraine and the urgent need for a peaceful resolution to the conflict, www.eronest.europarl.europa.eu/euronest/webdav/site/mySite/shared/ general_documents/fourth_ordinary_session_2015/resolutions/Ukraine_4thEuronestPA_EN_ draft.pdf, 28.06.2015.

Rezolucja Parlamentu Europejskiego z dnia 7 kwietnia 2011 r w sprawie przegladu europejskiej polityki sasiedztwa - wymiaru wschodniego, Dz. U. C 296 E z 2.10.2012.

Rezolucja Parlamentu Europejskiego z dnia 14 grudnia 2011 r. w sprawie przegladu europejskiej polityki sasiedztwa, Dz. U. C 168 E z 14.06.2013.

Rezolucja Parlamentu Europejskiego z dnia 23 października $2013 \mathrm{r}$ w sprawie europejskiej polityki sqsiedztwa: dażenie do wzmocnienia partnerstwa. Stanowisko Parlamentu Europejskiego w sprawie sprawozdań za rok 2012, www.europarl.europa.eu/sides/getDoc.do?pubRef=-// $\mathrm{EP} / / \mathrm{TEXT}+\mathrm{TA}+\mathrm{P} 7-\mathrm{TA}-2013-0446+0+\mathrm{DOC}+\mathrm{XML}+\mathrm{VO} / \mathrm{PL}, 28.05 .2015$.

Rezolucja Parlamentu Europejskiego z dnia 12 marca $2014 \mathrm{r}$. w sprawie oceny $i$ wyznaczenia priorytetów w stosunkach UE z państwami Partnerstwa Wschodniego, www.europarl.europa.eu/sides/getDoc.do?pubRef=-//EP//TEXT+TA+P7-TA-2014-0229+0+DOC+XML+VO//PL. 21.06 .2015 .

Rezolucja Zgromadzenia Parlamentarnego Euronest z dnia 3 kwietnia 2012 r. w sprawie umów handlowych między UE a jej partnerami z Europy Wschodniej, w tym pogtębionych $i$ kompleksowych stref wolnego handlu oraz pomocy UE $w$ tej dziedzinie, Dz. U. C 153 z 30.05.2012.

Rezolucja Zgromadzenia Parlamentarnego Euronest z dnia 28 maja $2013 \mathrm{r}$. w sprawie zblizenia ustawodawstw krajów Partnerstwa Wschodniego do ustawodawstwa UE w zakresie gospodarczym, Dz. U. C 338 z 19.11.2013.

Rezolucja Zgromadzenia Parlamentarnego Euronest z dnia 3 kwietnia $2012 \mathrm{r}$. w sprawie wyzwań dla przysztości demokracji, w tym wolnych i niezaleznych mediów w krajach Partnerstwa Wschodniego i krajach UE, Dz. U. C 153 z 30.05.2012.

Rezolucja Zgromadzenia Parlamentarnego Euronest z dnia 3 kwietnia 2012 r.w sprawie wzmocnienia spoleczeństwa obywatelskiego w państwach Partnerstwa Wschodniego, w tym wspólpracy pomiędzy rzadem a spoleczeństwem obywatelskim oraz reform wzmacniajacych pozycje spoteczeństwa obywatelskiego, Dz. U. C 153 z 30.05.2012.

Wspólna deklaracja przyjęta podczas szczytu partnerstwa wschodniego w Pradze, Praga, 7 maja 2009 r., register.consilium.europa.eu/pdf/pl/09/st08/st08435.pl09.pdf, 27.05.2010. 


\title{
Streszczenie
}

Artykuł ukazuje stanowisko PE wobec zagadnień, będących przedmiotem zainteresowania Partnerstwa Wschodniego. Autor, analizując to stanowisko, podkreśla istotną rolę PE w kształtowaniu unijnej polityki wschodniej, zwłaszeza w kontekście propagowania w ramach tej polityki idei i wartości demokratycznych. Należy podkreślić, że rozwój demokracji we wschodnioeuropejskich krajach partnerskich należy do szczególnych obszarów zainteresowania PE, który dostrzegając ich geopolityczne znaczenie, domaga się w licznie przyjmowanych stanowiskach zacieśnienia relacji z nimi, a nawet nadania tym państwom potencjalnej perspektywy europejskiej. Pogłębianie współpracy ze strony UE z tymi krajami uzależnia jednak PE od inkorporacji przez nie wartości definiowanych jako europejskie (demokracja, rządy prawa, ochrona praw człowieka itd.). Z racji bycia organem, który określa się „strażnikiem demokracji”, PE odgrywa rolę instytucji wpływu politycznego, co pozwala mu kształtować unijną politykę wschodnią w sposób wykraczający poza formalne, traktatowe uprawnienia.

Slowa kluczowe: Parlament Europejski, Partnerstwo Wschodnie, Euronest

\section{The European Parliament's standpoint towards the Eastern Partnership}

\begin{abstract}
Summary
This paper presents the attitude of the European Parliament to those issues that fall within the scope of interest of the Eastern Partnership. In the analysis of this attitude, the author stresses the significant role the EP has played in developing EU Eastern policy, in particular as concerns the promotion of democratic ideas and values within the scope of this policy. It should be emphasised that the EP is exceptionally interested in the advancement of democracy in East European partner countries, whose geopolitical significance the EP appreciates, frequently calling for the tightening of relations with these countries, and even opening European prospects to them. The deepening of cooperation between the EU and East European countries is conditioned by the EP by their adoption of what is called European values (i.e. democracy, rule of law, protection of human rights, etc.). Acting as the 'guard of democracy,' the EP is an institution of political influence which allows it to shape Eastern policy in ways that go beyond the formal rights vested in it by the treaties.
\end{abstract}

Key words: European Parliament, Eastern Partnership, Euronest 